\title{
MANAJEMEN STRATEGIK KEPALA MADRASAH DALAM PENINGKATAN MUTU LEMBAGA PENDIDIKAN
}

\author{
Ali Mashar \\ IAI An-Nur Lampung Selatan \\ Jl. Pesantren No.01, Sidoharjo, Kec. Jati Agung, Kabupaten Lampung Selatan, \\ Lampung 35365 \\ Email: alimashar1990@gmail.com
}

\begin{abstract}
ABSTRAK
Mutu lembaga pendidikan akan mengalami peningkatan jika subjek pendidikan mampu mengelola manajemen strategik dengan baik. Tujuan dari penelitian ini adalah ingin mengetahui bagaimana manajemen strategik yang dilakukan oleh Kepala MAN 1 Tulungagung dan Kepala MAN 3 Tulungagung yang selama ini sukses mengantarkan peserta didiknya meraih prestasi di bidang akademik maupun bidang lainnya. Metode yang digunakan dalam penelitian ini adalah dengan pendekatan kualitatif dengan desain studi kasus yang berupaya menelaah sebanyak mungkin data mengenai subjek yang diteliti. Sumber data dalam penelitian ini adalah kepala madrasah, para guru dan beberapa siswa di MAN 1 dan MAN 3 Tulungagung. Dalam mengumpulkan data, peneliti menggunakan teknik wawancara mendalam, observasi partisipan, dan studi dokumentasi. Hasil penelitian menunjukkan bahwa peningkatan mutu lembaga pendidikan dapat dicapai dengan meningkatkan profesionalisme semua stafnya sehingga mampu mengerjakan semua tugas dengan sebaikbaiknya.
\end{abstract}

Kata kunci: Manajemen Strategik, Pelaksanaan, Pengawasan

\section{ABSTRACT}

The quality of educational institutions will increase if the subject of education is able to manage strategic management well. The purpose of this study was to find out how strategic management carried out by the Head of Tulungagung MAN 1 and Head of MAN 3 Tulungagung which had so far successfully delivered students to achieve achievements in academic and other fields. The method used in this study is a qualitative approach with a case study design that seeks to examine as much data as possible about the subject under study. The data sources in this study were the head of the madrasa, the teachers and several students in MAN 1 and MAN 3 Tulungagung. In collecting data, researchers used in-depth interviewing techniques, participant observation, and documentation studies. The results of the study show that improving the quality 
of educational institutions can be achieved by increasing the professionalism of all staff so that they are able to do all the tasks properly.

Key Words: management strategic, actuating, controling

\section{PENDAHULUAN}

Mutu produk pendidikan akan dipengaruhi oleh sejauh mana lembaga mampu mengelola seluruh potensi secara optimal mulai dari tenaga kependidikan, peserta didik, proses pembelajaran, sarana pendidikan, keuangan dan termasuk hubungannya dengan masyarakat (Hidayat, 2016). Dan kepemimpinan kepala sekolah sangat menunjang akan tercapainya pengelolaan sekolah yang efektif dan efisien (Apriliana, Kristiawan, \& Hafulyoh, 2016)

Pelaksanaan manajemen sekolah yang efektif dan efisien menuntut pelaksanaan manajemen secara terpadu dan terintegrasi dalam pengelolaan bidang-bidang kegiatan manajemen pendidikan, melalui manajemen sekolah yang efektif dan efisien tersebut, diharapkan dapat memberikan konstribusi terhadap peningkatan kualitas pendidikan secara keseluruhan. Manajemen pendidikan merupakan alternatif strategis untuk meningkatkan kualitas pendidikan bahwa manajemen sekolah merupakan salah satu faktor yang mempengaruhi kualitas pendidikan, manajemen sekolah secara langsung akan mempengaruhi belajar, waktu mengajar dan proses pembelajaran (Mulyasa, 2002)

Pengembangan, peningkatan dan perbaikan pendidikan harus dilakukan secara holistik dan simultan, tidak boleh parsial walaupun mungkin dilakukan bertahap, perbaikan sektor kurikulum, tenaga guru dan fasilitas serta sarana pembelajaran, tidak akan terlalu membawa perubahan signifikan jika tidak disertai dengan perbaikan pola dan kultur manajemen yang mendukung perubahan-perubahan tersebut, dinamika guru dalam pengembangan program pembelajaran tidak akan bermakna bagi perbaikan proses dan hasil belajar siswa, jika manajemen sekolahnya tidak memberikan peluang tumbuh dan berkembangnya kreatifitas guru tersebut, demikian pula penambahan dan penguatan sumber belajar berupa perpustakaan dan laboratorium tidak akan memberikan perhatian serius dalam optimalisasi pemanfaatan sumber belajar tersebut dalam proses belajar siswa. Manajemen memang merupakan sesuatu yang amat bermakna dalam perubahan menuju sebuah perbaikan (Rosyada, 2004)

Perubahan yang terjadi pada gilirannya akan mempengaruhi tata nilai kehidupan masyarakat yang mungkin sama sekali baru dan berbeda dengan gaya nilai yang sekarang dianut masyarakat, proses perubahan kesiapan lembaga-lembaga pendidikan dan institusi sosial lainnya menjadi sangat penting, sebab masyarakat yang berada pada proses transisi kultural sangat labil pada berbagai benturan nilai dan salah satunya adalah institusi sosial dan kultural yang diharapkan dapat berperan besar dalam mengatur irama perubahan tersebut adalah lembaga pendidikan (Sholeh, 2004)

Pengembangan secara normatif serta pemahaman akan potensi dan tuntutan lingkungan strategis, sangat diperlukan sebagai dasar pengembangan 
pendidikan di sekolah yang secara konseptual akan dapat diterima oleh logika, secara kultural sesuai dengan budaya bangsa dan secara politis dapat diterima oleh masyarakat (Sholeh, 2004)

Pengaruh masyarakat terhadap sekolah sebagai lembaga sosial, terasa amat kuat, dan pengaruh pula kepada para individu-individu yang ada dalam lingkungan sekolah, lingkungan dimana sekolah berada, merupakan masyarakat yang bersifat kompleks, terdiri dari berbagai macam tingkatan masyarakat yang saling melengkapi dan bersifat unik sebagai akibat latar belakang dimensi budaya yang beraneka ragam (Wahjosumidjo, 2002)

Tindakan sistem pendidikan nasional diantaranya pendidikan peserta didik, tujuan pendidikan, relasi pendidikan dan struktur sosio kultural, merupakan unsur-unsur yang harus diatur dan dikendalikan secara definitif dan bersifat formal, sesuai dengan aspek-aspek nasionalisme dalam lingkungan bangsa Indonesia. Tindakan pendidikan yang berlangsung dalam situasi pendidikan berdasarkan sistem universal di bidang pendidikan yang memiliki sekurang-kurangnya lima unsur, yang terdapat juga di lingkungan pendidikan yang dilembagakan sebagai bagian dari Sistem Pendidikan Nasional. Kelima unsur yang terdiri dari pendidikan anak didik, tujuan pendidikan, relasi pendidikan dan struktur sosio kultural, merupakan unsur-unsur yang harus diatur dan dikendalikan secara definitif dan bersifat formal, sesuai dengan aspek-aspek nasionalisme dalam kehidupan bangsa Indonesia. Dalam pelembagaan inilah terbentuk berbagai jenis organisasi kerja yang memerlukan kegiatan manajemen, agar sebagai proses kerja sama (organisasi dalam arti dinamis) dapat mencapai tujuan pendidikan nasional secara efektif dan efisien (Nawawi, 2003)

Ilmu pengetahuan itu hanya bisa diperoleh melalui pendidikan. Dalam pendidikan harus mempunyai tujuan yang jelas dan terarah. Sedangkan tujuan pendidikan Islam harus sesuai dengan hakekat kejadian manusia yaitu sebagai hamba Allah yang patuh dan khalifah Allah di muka bumi ini, jadi usaha apa yang perlu dilaksanakan, dapat dikategorikan sebagai berikut : guru (pengajar), murid (yang belajar), bahkan pelajaran (kurikulum dan silabus) dan peralatan (fasilitas pendidikan) yang akan memberikan dampak ilmu pengetahuan dan teknologi (Amiruddin, 2000)

Pemerintah, dalam hal ini Menteri Pendidikan Nasional telah mencanangkan Gerakan Peningkatan Mutu Pendidikan pada tanggal 2 Mei 2002 dan lebih terfokus lagi setelah diamanatkan dalam Undang-Undang No: 20/2003 tentang Sistem Pendidikan Nasional. Bahwa pendidikan nasional berfungsi mengembangkan kemampuan dan membentuk watak serta peradaban bangsa yang bermanfaat dalam rangka mencerdaskan kehidupan bangsa.

Upaya mencerdaskan kehidupan bangsa menjadi tanggung jawab pendidikan terutama dalam mempersiapkan peserta didik menjadi subyek yang bertaqwa kepada Tuhan yang Maha Esa, berakhlaq mulia, tangguh, kreatif, mandiri, demokrasi dan profesional pada bidangnya. Ketentuan tersebut telah diundangkan dalam Undang-Undang SISDIKNAS Tahun 2003, pasal 52 ayat 1, bahwa pengelolaan satuan pendidikan anak usia dini, pendidikan dasar dan pendidikan menengah berbasis sekolah. 
Usaha untuk mewujudkan lembaga pendidikan Islam yang konsisten dengan kualifikasi yang unggul memerlukan langkah-langkah praktis. Lembaga pendidikan Islam seperti sekolah, pertama-tama dituntut untuk melakukan perubahan-perubahan strategis dalam bidang manajemen, dalam hal ini dituntut adanya visi yang baik dan bisa dipahami semua warga madrasah, adanya tanggung jawab, munculnya sens of belong atau rasa memiliki, kemampuan membangkitkan semangat karyawan menuju terciptanya sekolah yang berkualitas.

Perubahan mendasar tersebut berada pada perubahan pengelolaan pendidikan, dari pengelolaan sentralistik menjadi desentralistik. Pengelolaan pendidikan dengan berorientasi "keputusan pelanggan" ini dilakukan bertahuntahun telah menjadi kebiasaan, sehingga ketika diharapkan berubah masih saja yang dilakukan perubahan sepenggal-sepenggal. Salah satu alternatif yang harus dilakukan oleh setiap satuan pendidikan adalah mereset pengelolaan pendidikan dengan menerapkan manajemen strategik.

Pendidikan akan mengalami peningkatan apabila subyek pendidikan yang ada dalam pembahasan ini mampu mengelola manajemen strategi dengan baik. Manajemen dapat dipahami sebagai sebuah proses pemanfaatan terhadap sumber daya yang ada dalam organisasi, baik sumber manusia maupun sumber-sumber yang lain melalui proses perencanaan, pengorganisasian, penggerakan dan pengontrolan yang dilakukan secara sistematis. Oleh karena itu, keberhasilan seorang manajer atau pemimpin dalam mengelola organisasi sangat tergantung pada kemampuannya dalam mendayagunakan para anggota yang ada dalam organisasi untuk melaksanakan tugasnya, baik tugas yang bersifat strategik, teknis maupun operasional. Dengan dapat memanfaatkan segala sumber yang ada dengan baik maka akan sangat mendukung tercapainya tujuan atau cita-cita organisasi secara efektif dan efisien.

Manajemen strategik terdiri atas kata manajemen dan strategik yang diartikan sebagai rangkaian kegiatan pengambilan keputusan yang bersifat mendasar dan menyeluruh disertai penetapan cara melaksanakanya, yang dibuat oleh manajemen puncak dan diimplementasikan oleh seluruh jajaran dalam suatu organisasi untuk mencapai tujuannya.

Secara umum manajemen strategik dapat diartikan sebagai sebuah serangkaian keputusan dan tindakan mendasar yang dibuat oleh manajemen puncak dan diimplementasikan oleh seluruh jajaran suatu organisasi dalam rangka pencapaian tujuan organisasi tersebut (Siagian, 2000). Selain itu diperlukan juga strategi peningkatan mutu pendidikan yaitu peningkatan mutu pendidikan yang berorientasi keterampilan atau broad based education dan peningkatan mutu pendidikan berorientasi akademik atau hight based education (Fadjar, 2005)

Manajemen strategik diarahkan untuk mengembangkan lembaga pendidikan madrasah agar benar-benar berdaya guna, menjadi bagian atau gerbong perubahan kehidupan masyarakat muslim di Indonesia, terutama melalui peningkatan kualitas administratif penyelenggara pendidikan di madrasah, kualitas personalia atau ketenagaan, kualitas manajemen operatif madrasah, serta kualitas pembelajaran dan lulusan madrasah. Selain itu dalam manajemen strategik terdapat beberapa komponen yang saling berkaitan dan 
saling berhubungan antara satu sama lain yang bergerak menuju tercapainya tujuan organisasi, seperti komponen, visi, misi, tujuan strategik organisasi, tujuan operasional, serta pelaksanaan fungsi-fungsi manajemen berupa fungsi perencanaan, pengorganisasian, fungsi kontrol dan evaluasi serta umpan balik.

Fungsi manajemen terdiri dari fungsi perencanaan, fungsi pengorganisasian, fungsi penggerakan atau fungsi memimpin dan fungsi pengawasan. Dari beberapa fungsi manajemen tersebut sebenarnya berwujud kegiatan-kegiatan yang berurutan dan berhubungan antara satu dengan yang lain atau satu kegiatan menjadi syarat bagi kegiatan lainnya.

Fungsi manajemen yang pertama adalah perencanaan. Perencanaan itu sendiri merupakan aktivitas pengambilan keputusan tentang apa yang akan dicapai, tindakan apa yang akan diambil dalam rangka pencapaian tujuan, dan siapa saja yang akan melaksanakan tujuan tersebut (Burhanudin, 1994). Proses perencanaan itu sendiri memiliki langkah-langkah yang harus dilakukan, diantaranya adalah penentuan tujuan, menentukan tindakan untuk mencapai tujuan, mengembangkan dasar pemikiran tentang masa depan, menganalisa alternatif tindakan dan mengimplementasikan rencana dan evaluasi hasil kerja. Selain itu, dalam perencanaan paling tidak harus meliputi apa yang akan dikerjakan, mengapa dikerjakan, siapa yang akan mengerjakan, dan bagaimana mengerjakannya (Soperadi, 1988)

Perencanaan merupakan suatu penetapan keputusan atau perumusan tujuan/sasaran yang ingin dicapai sebelum melaksanakan kegiatan yang sesungguhnya. Dengan menetapkan apa, mengapa, siapa, dimana, bagaimana, dengan cara apa, dan berapa lama suatu kegiatan tersebut akan dilaksanakan akan memudahkan organisasi bergerak menuju sasaran atau cita-citanya. Karena itu dalam dunia pendidikan perencanaan merupakan pedoman yang harus dibuat dan dilaksanakan sehingga usaha pencapaian tujuan pendidikan dapat tercapai dengan efektif dan efisien.

Perencana strategi adalah mereka yang mempunyai posisi paling tinggi dalam sebuah organisasi atau lembaga pendidikan, sebab mereka menitikberatkan pada keterampilan konseptual dibanding dengan administrasi dan teknik sehingga para perencana strategi lebih general daripada spesialis.

Perencanaan strategi merupakan serangkaian keputusan dan tindakan mendasar yang dibuat oleh menejemen puncak dan diimplementasikan oleh seluruh komponen organisasi dalam rangka mencapai tujuan organisasi. Di beberapa organisasi atau perusahaan besar, perencana strategi dibantu oleh staf-staf ahli perencananya dilatih menggunakan teknik-teknik menejemen strategi. Para staf-staf tersebutlah yang akan membantu untuk menyediakan data, analisa dan rekomendasi dari beberapa aspek menejemen strategi seperti mengidentifikasi peluang-peluang yang baru, memantau keadaan lingkungan organisasi atau lembaga, meninjau dan mengevaluasi kinerja strategis, melakukan analisis alternatif strategis dan lain-lain (Siagian, 2000)

Stoner dan Wankel sebagaimana dikutip dalam Siswanto (2011) memperkenalkan perencanaan strategi atau strategy planning sebagai proses pemilihan tujuan organisasi, penentuan kebijakan dan program yang diperlukan untuk mencapai sasaran tertentu dalam rangka mencapai tujuan dan penetapan metode yang dibutuhkan guna menjamin agar kebijakan dan program strategis tersebut dapat dilaksanakan. Definisi tersebut secara 
komprehensif dapat dipadukan menjadi proses perencanaan jangkan panjang yang sifatnya formal untuk menentukan dan mencapai tujuan organisasi atau lembaga.

Perencanaan strategis memiliki lima karakter, yaitu pertama pertanyaan dan memberikan jawaban atas pertanyaan tersebut, kedua kerangka kerja pembuatan keputusan harian, ketiga jangka waktu yang panjang, ke empat pemusatan pada energy dan sumberdaya, dan kelima keterlibatan manajemen puncak. (Siswanto, 2011) Kelima karakter tersebut menegaskan pada keunggulan perencanaan strategis yang selalu mengedepankan visi, berorientasi pada proses dan berkesinambungan, beradaptasi dengan dinamika lingkungan antisipatif dan fleksibel terhadap berbagai perubahan yang terjadi. Dengan begitu berarti perencanaan strategis merupakan suatu kegiatan perencanaan dari sebuah organisasi dimana menejemen puncak sangatlah penting keberadaannya dalam mengembangkan organisasi atau lembaga pendidikan yang dipimpinnya dengan selalu memperhatikan para bawahannya.

Fungsi manajemen yang kedua adalah organizing atau pengorganisasian. Pengorganisasian sebagai suatu proses bagaimana pekerjaan diatur dan dialokasikan diantara para anggota sehingga tujuan organisasi itu dapat tercapai secara efektif dan efisien. Pengorganisasian dapat dipahami sebagai suatu aktivitas mengatur dan mengalokasikan sumber daya yang tersedia dalam organisasi pada tempat yang tepat sesuai dengan jenis kerja dan kemampuan masing-masing, serta menciptakan kerjasama dalam organisasi yang teratur. Dengan demikian tugas yang diberikan kepada anggota dalam organisasi akan dapat berjalan dengan baik dan pada akhirnya akan dapat mendukung ketercapaian tujuan organisasi secara efektif dan efisien.

Fungsi manajemen yang ketiga adalah actuating atau pelaksanaan pergerakan. Penggerakan merupakan pengarahan untuk membuat atau mendapatkan para karyawan melakukan apa yang diinginkan, dan harus mereka lakukan (Handoko, 2012). Menurut Burhanuddin (1994) penggerakan merupakan keseluruhan proses pemberian motivasi bekerja kepada bawahan sedemikian rupa sehingga mereka dapat bekerja dengan ikhlas demi tercapainya tujuan organisasi dengan efisien dan ekonomis. Selanjutnya Soepardi (1988) mengemukakan bahwa penggerakan adalah upaya untuk menggerakkan atau mengerahkan man power (tenaga kerja) serta mendayagunakan fasilitas yang ada dalam rangka melaksanakan pekerjaan organisasi bersama.

Fungsi manajemen yang ke empat adalah controlling atau pengawasan. Pengawasan dapat dipahami sebagai kegiatan mengkoreksi dan menilai suatu kegiatan untuk menjamin pelaksanaan dapat mencapai tujuan atau standar yang telah ditetapkan. Dengan adanya pengawasan, maka dapat melakukan umpan balik serta melakukan perbaikan kekurangan-kekurangan yang dialami oleh organisasi. Proses pengawasan dapat dibagi menjadi tiga tahap, yaitu menetapkan standar pelaksanaan, pengukuran pelaksanaan pekerjaan dibandingkan dengan standar, dan menentukan kesenjangan antara pelaksanaan dengan standar dan rencana (Fattah, 2016).

Manajemen pada dasarnya memiliki prinsip universal yang bisa diterapkan dibidang atau organisasi apa saja termasuk dalam bidang 
pendidikan. Manajemen pendidikan adalah pengelolaan kegiatan pendidikan dengan memanfaatkan seluruh fasilitas baik manusia maupun bukan manusia yang ada secara efektif dan efisien untuk mencapai tujuan yang telah ditetapkan lebih dulu (Soperadi, 1988)

Burhanuddin (1994) mengemukakan administrasi atau manajemen pendidikan dilihat dari suatu gugusan substansi, manajemen pendidikan dapat diklasifikasi menjadi pengelolaan pengaturan, pengelolaan siswa, pengelolaan personil, pengelolaan peralatan, pengelolan gedung, pengelolaan keuangan dan pengelolaan hubungan dengan masyarakat. Demikian juga dengan Siagian (2000) telah mengelompokkan pendidikan ke dalam tiga kelompok yaitu pertama pengelolaan personil yang meliputi pengelolaan personil guru, staf sekolah dan murid, kedua pengelolaan kurikulum yang meliputi penyusunan kurikulum, pembinaan kurikulum seperti pembagian tugas mengajar, pembuatan silabi, persiapan harian mingguan dan sebagainya, dan tiga pengelolaan material yang meliputi kegiatan manajemen material gedung sekolah, alat-alat perlengkapan sekolah, keuangan dan sebagainya.

Dengan demikian manajemen pendidikan dapat dipahami sebagai usaha untuk memanfaatkan atau mendayagunakan semua sumber pendidikan yang ada seperti kurikulum, guru dan pegawai, siswa, sarana dan sebagainya dengan menggunakan fungsi-fungsi manajemen seperti perencanaan, pengorganisasian, pelaksanaan dan pengawasan dalam memanfaatkan semua sumber tesebut untuk mencpai tujuan pendidikan secara efektif dan efisien.

Manajemen strategik sangat pas diterapkan untuk mencapai mutu pendidikan yang maksimal. MAN 1 dan MAN 3 Tulungagung adalah dua lembaga pendidikan formal yang sama-sama dibawah naungan Kementrian Agama. Lembaga ini juga sering mengantarkan anak didiknya dalam hal meraih prestasi, baik dalam bidang akademik maupun bidang lainnya. Tentunya, kedua lembaga ini dalam meraih prestasi tidak bisa dilepaskan dari peran kepala madrasah sebagai penanggung jawab keberhasilan sekolah dalam peningkatkan mutu lembaga pendidikan. Oleh karena itu penulis sangat tertarik untuk melakukan penelitian tentang bagaimanakah manajemen strategik kepala madrasah di MAN 1 dan MAN 3 Tulungagung.

\section{METODE}

Metode penelitian yang digunakan dalam penelitian ini adalah pendekatan kualitatif karena berupaya memahami dan mengkaji fenomena atau peristiwa, orang, objek, atau proses yang terkait dengan bagaimana manajemen strategik kepala madrasah dalam meningkatkan mutu lembaga pendidikan di MAN 1 dan MAN 3 Kabupaten Tulungagung. Penelitian kualitatif menurut Sukmadinata (2011) ditujukan untuk memahami fenomena-fenomena sosial dari sudut pandang atau perspektif partisipan. Dimana partisipan itu sendiri adalah orang-orang yang diajak berwawancara, diobservasi, diminta memberikan data, pendapat, pemikiran dan persepsinya tentang suatu hal.

Penelitian ini dilakukan dengan cara mengamati dan menyelidiki semua objek yang diteliti dengan mengungkapkan semua fakta yang ada pada saat penelitian berlangsung. Jenis penelitian yang digunakan adalah desain studi kasus yang berupaya menelaah sebanyak mungkin data mengenai subjek yang diteliti. Sumber data dalam penelitian ini adalah kepala madrasah, para guru 
dan beberapa siswa di MAN 1 dan MAN 3 Kabupaten Tulungagung. Dalam mengumpulkan data, peneliti menggunakan teknik wawancara mendalam, observasi partisipan, dan studi dokumentasi.

\section{HASIL DAN PEMBAHASAN \\ Pelaksanaan Kepala Madrasah MAN 1 Tulungagung dalam Peningkatan Mutu Pendidikan}

Sebagai pemimpin pendidikan, kepala madrasah memegang peranan yang penting dalam meletakan pondasi pendidikan bagi pengelolaan dan pengembangan sumber daya manusia di lembaganya. Oleh karena itu, kepala madrasah harus membekali dirinya dengan jiwa kepemimpinan, inovasi, kompetensi, skill dan kreativitas yang tinggi agar dapat berkembang dengan pesat (Widiarochmawati, 2010)

Berdasarkan hasil wawancara dengan para guru, dapat diketahui bahwa Kepala MAN 1 Tulungagung mengupayakan keseimbangan sistem pendidikan di sekolah dalam rangka upaya peningkatan mutu proses dan hasil belajar siswa. Caranya adalah dengan mengoptimalkan pelaksanaan pembelajaran tuntas, memberikan bimbingan belajar kepada siswa dalam bentuk layanan khusus, mengadakan penambahan jam pembelajaran, mengembangkan kurikulum muatan lokal yang relevan dengan kebutuhan siswa, mengadakan pembinaan akademis dan non akademis bagi siswa yang berprestasi, melengkapi sarana fasilitas pembelajaran yaitu penyediaan laboratorium IPA, laboratorium komputer, perpustakaan dan adanya pendampingan siswa, baik yang berprestasi maupun yang tidak berprestasi, memberikan bimbingan dan pengarahan dalam kegiatan ekstrakurikuler. Kepala MAN 1 Tulungagung juga melakukan pengecekan ruang kelas supaya kondisi fisik bangunan selalu terpantau, sehingga siswa merasa nyaman untuk belajar, melakukan renovasi, perawatan taman agar dapat berfungsi sebagai taman yang memberikan suasana yang nyaman dan bersih, mengembangkan rasa percaya diri bagi guru, dengan melakukan pendekatan kepada guru secara personal melalui sharing yang dilakukan setiap ada kesempatan.

Kepala MAN 1 Tulungagung juga menyatakan bahwa sekolah mengembangkan profesionalisme semua stafnya sehingga mampu mengerjakan semua tugas dengan sebaik-baiknya. Mengefektifkan kegiatan MGMP, melibatkan organisasi pembinan profesi guru, seperti Kelompok Kerja Guru (KKG), Musyawarah Guru Mata Pelajaran (MGMP), Musyawarah Kerja Kepala Madrasah (MKKM), dan Musyawarah Kerja Penilik Madrasah. Memanfaatkan hari besar keagamaan untuk kegiatan kerohanian, mengadakan dan mengikutsertakan guru dalam kegiatan lokakarya maupun seminar baik lokal maupun regional, untuk para pendidik yang sudah berpengalaman perlu diberikan kesempatan untuk mengikuti penataran yang dilaksanakan oleh lembaga inservice training yang juga sudah terakreditasi. Selain itu, para guru juga disyaratkan untuk mengikuti pendidikan profesi yang dapat dilaksanakan oleh lembaga tenaga kependidikan (LPTK) yang juga harus terakreditasi, serta menyarankan guru memiliki lulusan minimal $S 1$ dan yang sudah tamat $S 1$ untuk melanjutkan S2 bahkan ada yang akan melanjutkan kejengjang S3. Secara administrasi Kepala MAN 1 Tulungagung membuat peraturan yang harus ditaati semua warga sekolah, dan secara pribadi Kepala MAN 1 Tulungagung selaku 
pimpinan di sini berusaha memberikan teladan yang baik dan juga melakukan pengawasan kepada siswa apabila ada gejala-gejala kenakalan maka pihak sekolah akan memberikan pendekatan kepada siswa-siswa tersebut dan memberikan pengarahan dan nasihat sehingga perilaku siswa tersebut dapat berubah. Dengan sikap kekeluargaan yang diterapkan, pihak sekolah berharap sikap kedisiplinan, keakraban yang ada benar-benar tumbuh dari kesadaran dalam diri masing-masing (Riyadi, 2015).

Kepala sekolah juga menyatakan bahwa seluruh staf dan tenaga kependidikan lain yang ada di MAN 1 Tulungagung harus berperan dalam memberikan pelayanan kepada siswa baik memberikan kemudahan dalam melakukan pembayaran, maupun pemberian bimbingan dalam pemanfaatan fasilitas yang ada di sekolah berupa laboratorium baik IPA maupun komputer sehingga siswa merasa terbantu dengan adanya pihak tersebut (Riyadi, 2015).

Dalam melaksanakan peran sebagai motivator, upaya yang dilakukan kepala sekolah dalam peningkatan mutu dilakukan dengan pemberian reward dan punishment kepada guru, staf dan siswa. Berdasarkan hasil wawancara bahwa tindakan kepala madrasah terhadap guru yang melakukan pelanggaran peraturan madrasah tergantung dari bagaimana pelanggaran itu dilakukan. Jika pelanggaran ringan, kepala madrasah memberikan teguran secara lisan namun bila pelanggaran dirasa berat maka kepala madrasah akan memberikan sanksi administrasi kepada guru tersebut atau bahkan melaporkan kepada kantor Kementerian Agama Kabupaten Tulungagung apabila pelanggaran dilakukan sangat berat, hal ini merupakan strategi kepala madrasah dalam menjaga mutu, kepercayaan orang tua siswa dan masyarakat terhadap MAN 1 Tulungagung (Zainudin, 2015).

Pandangan para siswa terhadap kepala madrasah adalah mereka menganggap bahwa kepala madrasah merupakan orang yang baik dan tegas namun mengerti perasaan siswa sehingga nasihat kepala madrasah mudah diterima. Kepala madrasah juga memberikan penghargaan kepada siswa yang berprestasi dan memberikan bimbingan khusus kepada siswa yang kurang berprestasi. Terhadap siswa yang melakukan pelanggaran, kepala madrasah tidak langsung memberikan hukuman tetapi memberikan nasihat dulu, kalau masih belum berubah masih diberi peringatan, namun bila pelanggaran sangat parah akan diberi sanksi.

\section{Pengawasan Kepala Madrasah MAN 1 Tulungagung dalam Peningkatan Mutu Pendidikan}

Pengawasan dimaksudkan sebagai upaya untuk mengetahui dan mengamati terhadap kegiatan yang sedang dilakukan oleh sekolah maupun terhadap unsur-unsur organisasi, meliputi sumber daya yang tersedia, sasaran, proses, hasil dan pengaruh rencana atau program yang sedang dilaksanakan. Pengawasan dilaksanakan untuk mengidentifikasi ketepatan kegiatan terhadap hasil yang dicapai dan terhadap rencana yang telah ditetapkan, mengetahui ada tidaknya penyimpangan pelaksanaan dari suatu rencana dan mengupayakan perbaikan dan pengembangan dalam mencapai tujuan yang telah ditetapkan.

Pengawasan yang dilakukan oleh Kepala MAN 1 Tulungagung dalam peningkatan mutu pendidikan adalah dengan melakukan supervisi pada saat 
para guru mengajar, dan memberikan tanggapan apakah cara mengajar dan media yang para guru gunakan sudah sesuai dengan materi yang diajarkan. Supervisi kepala madrasah ini terutama ditujukan kepada guru yang masih relatif muda dan dirasa masih perlu pembimbingan (Utami, 2015).

Kepala MAN 1 Tulungagung pun memeriksa rencana pembelajaran yang dibuat oleh para guru melalui program MONEV (Monitoring dan Evaluasi) yang dilakukan tiap 2 bulan sekali. Dari program tersebut kepala madrasah memberikan saran-saran untuk perbaikan baik dari metode, maupun media untuk disesuaikan dengan materi ajar yang akan disampaikan, sehingga ke depan diharapkan tidak ada kesalahan serupa dan menjadi masukan dan evaluasi bagi guru lain terhadap rencana pembelajaran mereka sehingga diharapkan dengan evaluasi tersebut kualitas pembelajaran guru meningkat (Utami, 2015).

Terkait dengan evaluasi, kepala MAN 1 Tulungagung menyatakan bahwa melakukan monitoring baik secara akademik maupun non akademik. Akademik dilakukan secara rutin mengadakan pengecekan setiap kelas untuk melihat perangkat, teknik, metode dan evaluasi yang dilakukan guru. Non akademik melalui absensi, dan presensi pembinaan. Selain itu monitoring juga dilakukan dengan melihat kehadiran mereka dalam setiap kegiatan madrasah seperti hari-hari besar dan lain sebagainya, untuk peningkatan mutu karena madrasah yang sudah berjalan untuk memperbaiki mutu, tidak berangkat dari nol, melainkan dari kondisi yang dimiliki, setiap akhir tahun kami melakukan evaluasi untuk menilai tingkat ketercapaian sarana program yang telah ditetapkan untuk mengetahui seberapa besar tingkat keberhasilan program dapat direalisasikan (Riyadi, 2015).

\section{Pelaksanaan Kepala Madrasah MAN 3 Tulungagung dalam Peningkatan Mutu Pendidikan}

Fungsi utama pimpinan pada satuan pendidikan, seperti kepala madrasah adalah menciptakan situasi belajar mengajar sehingga guru-guru dapat mengajar dan murid-murid dapat belajar dengan baik. Dalam melaksanakan fungsi tersebut, kepala madrasah memiliki tanggung jawab ganda yaitu melaksanakan administrasi madrasah sehingga tercipta situasi belajar mengajar yang baik dan melaksanakan supervisi sehingga kompetensi guru bertambah dan menjadi professional (Baharun, 2017)

Madrasah diberikan kesempatan seluas-luasnya untuk mengurus dan mengatur pelaksanaan pendidikan pada masing-masing sekolah sesuai dengan paradigma MBM. Pelaksanaan pendidikan di madrasah-madrasah dalam tempat yang berlainan dimungkinkan untuk menggunakan sistem dan pendekatan pembelajaran yang berbeda. Kepala madrasah diberikan keleluasaan untuk mengelola pendidikan dengan jalan mengadakan serta memanfaatkan sumber daya pendidikan sendiri-sendiri asalkan sesuai dengan kebijakan dan standar yang ditetapkan pusat.

Sekolah diberikan otonomi untuk melakukan kebijakan-kebijakan yang sesuai dengan kebutuhan sekolah. Kebutuhan tersebut menyangkut kebutuhan fisik dan non fisik. Contoh dari kebutuhan fisik yaitu bangunan, buku, dan sebagainya yang pada intinya fisik yang mendukung SBM. Sedang non fisik termasuk di dalamnya sumber daya manusia, yaitu sekolah diberi kebebasan 
secara otonom untuk melakukan kebijakan sesuai kemampuan dan kebutuhan sehingga sekolah membuat skala prioritas (Huda, 2015).

Kemandirian yang dimiliki MAN 3 Tulungagung dalam hal kurikulum sangat terlihat jika dibandingkan dengan beberapa tahun kebelakang, hal itu tebukti bahwa pada jaman dahulu karikulum bersifat stagnan namun sekarang kurikulum bisa dinegosiasi atau fleksibel. Sifat fleksibel di sini terlihat dengan adanya muatan lokal yang di sesuaikan dengan keadaan lokal madrasah, di mana madrasah mengembangkan keterampilan menjahit dan mata pelajaran komputer untuk mempersiapkan peserta didik memasuki era komputerisasi, sehingga siswa yang sudah lulus dari madrasah memiliki keterampilan lebih yang berguna untuk masyarakat. Kegiatan ini juga ditunjang dengan adanya ruang keterampilan dan perlengkapan jahit serta laboratorium computer (Ma'arif, 2015).

Guru merupakan salah satu pihak yang bertanggang jawab dalam penyelenggaraan pendidikan yang bermutu karena guru merupakan pihak yang secara langsung berinteraksi dengan siswa sebagai pemakai jasa pendidikan dalam memberikan bimbingan belajar dan membantu siswa dalam memperoleh suatu ilmu selama siswa menjalam pendidikan di lingkungan sekolah, melalui perannya sebagai pengimplementasi program-program pengajaran. Banyak sekali upaya yang sudah dilakukan oleh para guru di MAN 3 Tulungagung dalam rangka meningkatkan mutu pendidikan, diantaranya adalah dengan mengoptimalkan pelaksanaan pembelajaran tuntas, memberikan bimbingan belajar kepada siswa dalam bentuk layanan khusus, mengadakan penambahan jam pembelajaran, mengembangkan kurikulum muatan lokal yang relevan dengan kebutuhan siswa, mengadakan pembinaan akademis dan non akademis bagi siswa yang berprestasi, melengkapi perangkat pembelajaran, memberikan bimbingan dan pengarahan dalam kegiatan ekstrakurikuler (Fahmi, 2015).

Upaya peningkatan mutu pendidikan di MAN 3 Tulungagung, pihak sekolah meningkatkan kualitas sumber daya manusia yang ada terutama guru. Cara yang dilakukannya adalah dengan mengefektifkan kegiatan MGMP, melibatkan organisasi pembinaan profesi guru, seperti Kelompok Kerja Guru (KKG), Musyawarah Guru Mata Pelajaran (MGNfP), Musyawarah Kerja Kepala Madrasah (MKKM), dan Musyawarah Kerja Penilik Madrasah. Disamping itu juga dengan memanfaatkan hari besar keagamaan untuk kegiatan kerohanian, mengadakan dan mengikutsertakan guru dalam kegiatan lokakarya maupun seminar baik lokal maupun regional, untak para pendidik yang sudah berpengalaman perlu diberikan kesempatan untuk mengikuti penataran yang dilaksanakan oleh lembaga inservice training yang juga sudah terakreditasi. Selain itu, para guru juga disyaratkan untuk mengikuti pendidikan profesi yang dapat dilaksanakan oleh lembaga tenaga kependidikan (LPTK) yang juga harus terakreditasi, serta menyarankan guru mengenyam pendidikan minimal S1 dan yang sudah tamat S1 untuk melanjutkan ke jenjang S2. Pihak sekolah MAN 3 Tulungagung juga melakukan kegiatan yang mendukung kelancaran proses belajar dan mengajar yang representatif, penciptaan suasana kondusif dengan cara menjaga keamanan dil ingkungan madrasah, baik di dalam maupun diluar madrasah, melalui pembuatan pagar sebagai pengamanan upaya adanya gangguan dari luar, serta melakukan pengecekan ruang kelas supaya kondisi 
fisik bangunan selalu terpantau, sehingga siswa merasa nyaman untuk belajar, melakukan renovasi, perawatan taman agar dapat berfungsi sebagai taman yang memberikan suasana nyaman dan bersih " (Huda, 2015).

Proses belajar mengajar merupakan suatu proses yang mengandung serangkaian perbuatan guru dan siswa atas dasar hubungan timbal balik yang berlangsung dalam situasi edukatif untuk mencapai tujuan tertentu. Dalam proses belajar mengajar tersirat adanya satu kesatuan kegiatan yang tak terpisahkan antara siswa yang belajar dan guru yang mengajar. Proses pembelajaran yang dilakukan di MAN 3 Tulungagung adalah dilaksanakan secara efektif dan efisien karena guru mempunyai berbagai kompetensi (kompetensi kognitif, kompetensi afektif, kompetensi psikomotorik), terampil mengajar, memiliki pribadi yang baik, mampu mengelola kelasnya, sehingga belajar para siswa berada pada tingkat optimal, memiliki dan menguasai perencanaan kegiatan belajar mengajar, melaksanakan kegiatan yang direncanakan dan melakukan penilaian terhadap hasil dari proses belajar mengajar (Fahmi, 2015).

\section{Pengawasan Kepala Madrasah MAN 3 Tulungagung dalam Peningkatan Mutu Pendidikan}

Kegiatan pengawasan ini bertujuan untuk mengetahui kondisi madrasah saat ini dalam segala aspeknya (seluruh komponen madrasah), kemajuan yang telah dicapai, maupun masalah-masalah yang dihadapi ataupun kelemahan yang dialami. Pengawasan di MAN 3 Tulungagung merupakan hal yang sangat penting untuk peningkatan mutu karena sebagai bentuk evaluasi madrasah yang sudah berjalan untuk memperbaiki mutu, tidak berangkat dari nol, melainkan dari kondisi yang dimiliki, setiap akhir tahun kepala MAN 3 Tulungagung melakukan evaluasi untuk menilai tingkat ketercapaian sarana program yang telah ditetapkan untuk mengetahui seberapa besar tingkat keberhasilan program dapat direalisasikan, serta sebagai bahan pembanding dan dasar target yang akan dicapai pada masa yang akan datang, evaluasi juga dilakukan terhadap kinerja guru, secara terjadwal dan secara mendadak, hal ini dilakukan sebulan sekali sehingga dalarn satu semester evaluasi terhadap guru dilakukan tiga kali, dan setiap evaluasi didukung dengan datadata yang jelas dan dapat dipertanggungjawabakan (Huda, 2015).

Kepala MAN 3 beserta para guru menyusun laporan penyelenggaraan program dan hasil yang dicapai kepada pihak yang berkepentingan yaitu, secara vertikal MAN 3 merupakan bagian dari lembaga yang lebih tinggi yaitu Kepala Kanwil kementerian Agama, up. Kepala Bidang Mapenda Islam/Bagais/TOS, Kantor kementerian Agama setempat, maka kami harus menyampaikan laporan sebagai bentuk pertanggungjawaban pelaksanaan tugas. Selain itu MAN 3 Tulungagung juga membuat laporan kepada komite sekolah sebagai pihak yang secara horizontal memiliki wewenang untuk meminta pertangguugjawaban kepada madrasah sebagai mitra keja (Huda, 2015). 


\section{Strategi Pelaksanaan dan Pengawasan Kepala MAN 1 Tulungagung dan MAN 3 Tulungagung dalam Peningkatan Mutu Pendidikan.}

Pelaksanaan peningkatan mutu pendidikan di MAN 1 Tulungagung dan MAN 3 Tulungagung sangat baik, hal ini karena kepala madrasah selalu memberikan masukan positif bagaimana melaksanakan tugas dan kewajibannya sesuai dengan prosedur yang berlaku di madrasah, serta mengikutsertakan para guru dan staf untuk mengikuti pelatihan-pelatihan, MGMP, dan seminar yang menunjang kompetensi individualnya, dan kompetensi profesionalnya.

Kepala madrasah juga selalu berusaha mengadakan hubungan timbal balik yang positif dengan semua guru dan karyawan, dan juga selalu mengadakan pembinaan dalam waktu-waktu tertentu dan memberikan motivasi yang positif kepada semua guru dan staf untuk meningkatkan kinerjanya. Kepala madrasah selalu mengusahakan adanya keserasian tugas dalam melaksanakan setiap kegiatan peningkatan mutu dan pengembangan madrasah yaitu implementasi setiap program madrasah yang direncanakan para PKM, BK, para wali kelas terutama kegiatan yang berkaitan dengan pengisian raport, pembinaan peserta didik, dan pembinaan ekstrakurikuler serta pembinaan les menjelang try out dan Ujian Madrasah serta Ujian Nasional yang dimaksudkan untuk mencapai sasaran dan tujuan madrasah.

Kepala madrasah juga selalu mengamati kinerja para guru yang sedang mengajar dan sangat aktif dalam membina anak-anak baik melalui kegiatan kulikuler maupun kegiatan ekstra kulikuler. Hal ini menandakan bahwa kepala madrasah mempunyai kepedulian yang tinggi pada peningkatan kualitas pendidikan melalui pelaksanaan kinerja madrasah. Disamping itu kepala madrasah juga mampu mensejahterakan, memberdayakan, punya komitmen yang tinggi, dan memiliki tujuan terhadap diri sendiri dan sekolah, mampu menuntun dan memotivasi bawahannya, memiliki keahlian teknis, berani mengambil resiko dengan penuh perhitungan, mampu bernegosiasi untuk kepentingan sekolah, memiliki jiwa kewirausahaan dan berani melaksanakan manajemen pendidikan berbasis madrasah.

Pelaksanaan KBM di MAN 1 dan MAN 3 Tulungagung dapat memberikan rasa aman, nyaman, tertib, betah dan bahagia kepada semua warga madrasah selama berada di lingkungan sekolah. Hal ini terbukti dengan adanya konstruksi bangunan yang kuat sesuai standar yang berlaku, penataan bangunanya indah dan menarik, master plan-nya teratur sehingga pencahayaan, sirkulasi udara dapat mendukung terhadap kesehatan penghuninya. Ukuran perabot, penataan, penempatan dapat mendukung rasa aman bagi seluruh warga madrasah.

MAN 1 Tulungagung dan MAN 3 Tulungagung memiliki petugas penjaga sekolah, gedung sekolah pun dikelilingi oleh pagar, jauh dari tempat kemaksiatan dan tempat-tempat yang dapat menimbulkan rasa tidak aman. Dalam pelaksanaan peningkatan mutu, hal ini menunjukkan bahwa kepala madrasah mampu melaksankan rencana yang baik untuk meningkatkan kualitas pendidikan. Disamping itu sarana dan prasarana madrasah dari tahun ke tahun selalu terdapat perbaikan dan penambahan. Kepala madrasah telah mengatur SOP (standar operasional dan prosedur) dalam setiap pelaksanaan tugas dan wewenang dari masing-masing kompenen yang ditindak lanjuti 
dengan pelaksanaan program kerja sesuai dengan rencana, dalam pelaksanaan peningkatan mutu pendidikan kepada madrasah mampu berinteraksi secara positif kepada bawahannya termasuk diantaranya para guru dan staf pendidikan lainnya yang dilakukan dalam setiap bertemu baik di madrasah maupun di luar selalu mengadakan motivasi.

Pengawasan dilakukan sebagai upaya untuk mengetahui dan mengamati terhadap kegiatan yang sedang dilakukan oleh madrasah maupun terhadap unsur-unsur organisasi, meliputi sumber daya yang tersedia, sasaran, proses, hasil dan pengaruh rencana atau program yang sedang dilaksanakan. Pengawasan dilaksanakan untuk mengidentifikasi ketepatan kegiatan terhadap hasil yang dicapai dan terhadap rencana yang telah ditetapkan, mengetahui ada tidaknya penyimpangan pelaksanaan dari suatu rencana dan pengupayaan perbaikan dan pengembangan dalam mencapai tujuan yang telah ditetapkan, dengan selalu mengadakan perbandingan antara penampilan kerja dngan rencana, perbandingan program yang dicapai dengan program yang direncanakan, perbandingan tujuan yang dicapai dengan tujuan yang diharapkan yang kesemuanya itu dilakukan secara periodik dan pengawasan pada akhir semester.

Pelaksanaan pengawasan strategi peningkatan mutu pendidikan di MAN 1 Tulungagung dan MAN 3 Tulungagung sangat baik, hal ini karena kepala madrasah selalu mengamati sejauhmana kegiata yang dilakukan bawahan terutama para PKM, wali kelas, guru dan staf pendidikan lainnya terlaksana sesuai dengan rencana sangat baik, hal ini karena kepala madrasah selalu mengadakan Pengawasan dan perbaikan secara periodik dalam mengadakan pengawasan selalu: a) menetapkan standar yang dijadikan alat pengukur dalam lingkup kerjanya sesuai dengan pedoman sertifikat guru dalam jabatan dan pedoman administrasi yang ditetapkan oleh Kementerian Agama; b) mengukur kegiatan sambil berpegang kepada standar yang telah ditetapkan tersebut; c) memperbaiki penyelewengan yang ditemukan dan selanjutnya memperbaiki segala bentuk penyelewengan dan kelemahan atau kesalahan yang telah dilakukan oleh para guru dan staf.

Kepala madrasah seringkali mengadakan monitoring dalam setiap pelaksanaan kegiatan, terutama pengadaan observasi dan supervisi akademik bagi para guru dan supervisi administrasi bagi para staf pendidikan, untuk mengetahui apakah program kerja yang telah direncanakan dapat terealisasikan sesuai dengan tujuan atau tidak. Jika telah sesuai dengan tujuan kepala madrasah memberikan apresiasi positif, dan bagi guru dan staf yang belum mampu merealisasikannya selalu mendapatkan pembinaan untuk memperbaiki tupoksinya.

Pengawasan dilaksanakan untuk mengidentifikasi ketepatan kegiatan terhadap hasil yang dicapai dan terhadap rencana yang telah ditetapkan, mengetahui ada tidaknya penyimpangan pelaksanaan dari suatu rencana dan mengupayakan perbaikan dan pengembangan dalam mencapai tujuan yang telah ditetapkan, dengan selalu mengadakan perbandingan antara penampilan kerja dengan rencana, perbandingan program yang dicapai dengan program yang direncanakan, perbandingan tujuan yang dicapai dengan tujuan yang diharapkan yang kesemuanya itu dilakukan secara periodik. 
Pengawasan pada akhir semester, yaitu pengawasan dalam meningkatkan mutu pendidikan di MAN 1 Tulungagung dan MAN 3 Tulungagung kepala madrasah selalu memperhatikan langkah-langkah utama dalam proses pengawasan terutama menetapkan standar alat ukur penilaian, mengukur kegiatan berdasar standar yang telah ditetapkan melalui observasi KBM dan observasi administrasi, serta memperbaiki kesalahan yang ditemukan dalam pelaksanaan tupoksi masing-masing guru dan staf.

\section{SIMPULAN}

Pelaksanaan strategi peningkatan mutu lembaga pendidikan yang dilakukan oleh MAN I dan MAN 3 Tulungagung dengan melakukan kebijakankebijakan yang sesuai dengan kebutuhan sekolah menyangkut kebutuhan fisik dan non fisik. Untuk meningkatkan mutu pendidikan, sekolah meningkatkan profesionalisme semua stafnya sehingga mampu mengerjakan semua tugas dengan sebaik-baiknya.

Pelaksanaan pengawasan peningkatan mutu pendidikan yang dilakukan MAN I dan MAN 3 Tulungagung dilaksanakan untuk mengetahui keberhasilan program guru, dan program sekolah dilakukan secara terjadwal dalam satu semester, setiap evaluasi didukung dengan data-data yang jelas dan dapat dipertanggungjawabkan, sebagai acuan dalam peningkatan mutu lembaga pendidikan yang akan datang.

\section{REFERENSI}

Amiruddin, T. (2000). Berorientasi Manajemen Pendidikan Islam di Era Indonesia Baru. Yogyakarta: UII Press.

Apriliana, E. R., Kristiawan, M., \& Hafulyoh. (2016). Kepemimpinan Kepala Madrasah dalam Mewujudkan Pembelajaran Efektif di Madrasah Ibtidaiyyah Rahmah El Yunusiyyah Diniyyah Puteri Padang Panjang. $\begin{array}{lllll}\text { Jurnal Elementary } \quad \text { Vol. } 4 & \text { No. } & 1, & \text { 1-22. }\end{array}$ http://dx.doi.org/10.21043/elementary.v4i1.1975

Aziz, A. (1989). Menyusun Rancangan Penelitian Kualitatif. Surabaya: Bamus BMPTSI.

Baharun, H. (2017). Peningkatan Kompetensi Guru Melalui Sistem Kepemimpinan Kepala Madrasah. At-Tajdid : Jurnal IImu Tarbiyah, Vol. 6 No. 1, hal. 1-26.

http://ejournal.stitmuhpacitan.ac.id/index.php/tajdid/article/view/38

Burhanudin. (1994). Analisis Administrasi dan Manajemen Pendidikan dalam Kepemimpinan Pendidikan. Jakarta: Depdikbud.

Fadjar, A. M. (2005). Holistika Pemikiran Pendidikan . Jakarta: PT Raja Grafindo Persada.

Fahmi, A. (28 September 2015). Wawancara Penelitian. Tulungagung. Tidak diterbitkan.

Fattah, N. (2016). Manajemen Stratejik Berbasis Nilai. Bandung: PT Remaja Rosdakarya.

Handoko, T. H. (2012). Manajemen. Yogyakarta: BPFE.

Hidayat, R. (2016). Manajemen Peningkatan Mutu Lembaga Pendidikan Islam di Kota Medan. Jurnal ISEMA : Islamic Educational Managemen Vol 1. No 1, hal. 13-29. https://doi.org/10.15575/isema.v1i1.4982 
Huda, K. (28 September 2015). Wawancara Penelitian. Tulungagung. Tidak diterbitkan.

Ma'arif, M. Z. (28 September 2015). Wawancara Penelitian. Tulungagung. Tidak diterbitkan.

Mulyasa. (2002). Manajemen Berbasis Sekolah, Konsep Strategi dan Implementasi. Bandung: Rosdakarya.

Nawawi, H. (2003). Manajemen Strategis. Yogyakarta: Gadjah Mada University Press.

Riyadi, S. (28 September 2015). Wawancara Penelitian. Tulungagung. Tidak diterbitkan

Rosyada, D. (2004). Paradigma Pendidikan Demokratis, Sebuah Model Pelibatan Masyarakat dalam Penyelanggaraan Pendidikan. Jakarta: Kencana.

Sholeh, A. R. (2004). Madrasah dan Pendidikan Anak Bangsa, Visi Misi dan Aksi. Jakarta: PT Raja Grafindo Persada.

Siagian, S. P. (2000). Manajemen Strategik. Jakarta: Bumi Aksara.

Siswanto, H. B. (2011). Pengantar Manajemen. Jakarta: Bumi Aksara.

Soperadi, I. (1988). Dasar-Dasar Administrasi Pendidikan. Jakarta: Depdikbud.

Sukmadinata, N. S. (2011). Metode Penelitian Pendidikan. Bandung: PT Remaja Rosdakarya.

Utami, S. (28 September 2015). Wawancara Penelitian. Tulungagung. Tidak diterbitkan.

Wahjosumidjo. (2002). Kepemimpinan Kepala Sekolah, Tinjauan Teoretik dan Permasalahannya. Jakarta: PT Raja Grafindo Persada.

Widiarochmawati, N. (2010). Kepemimpinan Kharismatik Wanita Kepala Sekolah Dasar di Kabupaten Tuban. Jurnal Prospektus VII, No 1, hal. 30. http://garuda.ristekdikti.go.id/documents/detail/61134

Zainudin, M. (28 September 2015). Wawancara Penelitian. Tulungagung. Tidak diterbitkan. 